\title{
ANALISIS FAKTOR-FAKTOR KESULITAN MEMBACA MENULIS DAN BERHITUNG SISWA KELAS 1 SD
}

\author{
Tiwi Mardika \\ SD N Pancurendang, Banyumas, Indonesia \\ Email: tiwimardika93@gmail.com
}

\begin{abstract}
The research was aimed at knowing what factors affected the difficulty in reading, writing, and computing in first grade elementary school. This used a descriptive research. The subject of this research were 39 students of grade 1 at SD Negeri 1 Pancurendang. The data were collected through observation, interview, and documentation. Based on the result of the research, most of the students were able to read, writ and compute well, but only two were not. The difficulties in reading, writing, and computing were affected by several factors such as teh family environment factor, the parent's attention, guidance and supervision which were very, important and influencing the student's interest and motivation as well as the student's environment in learning process. To overcome the difficulties in reading, writing and computing, the teacher and parents gave attention, training, and guidance so that the learning process could run well.
\end{abstract}

Keywords :Learning difficulties, Reading, Writing, Counting

\begin{abstract}
Abstrak. Penelitian ini merupakan penelitian deskriptif. Subyek dalam penelitian ini adalah seluruh siwa kelas 1 SD Negeri 1 Pancurendang yang berjumlah 39 siswa. Penelitian ini bertujuan untuk mengetahui faktor apa saja yang mempengaruhi kesulitan membaca, menulis dan berhitung. alat pengumpulan data diperoleh dari observasi, wawancara dan dokumentasi. Hasil penelitian sebagaian siswa sudah lancar dan bisa membaca, menulis dan berhitung tetapi ada 2 anak yang masih mengalami kesulitan membaca, menulis dan berhitung. Kesulitan membaca, menulis dan berhitung dipengaruhi oleh beberapa faktor yaitu faktor lingkungan keluarga perhatian orang tua, pendampingan dan pengawasan yang dianggap sangat penting dan mempengaruhi minat dan motivasi siswa serta lingkungan siswa pada proses pembelajaran. Strategi guru untuk mengatasi kesulitan membaca, menulis dan berhitung dengan memberikan perhatian, latihan, bimbingan oleh guru dan juga orang tua agar proses pembelajaran dapat berjalan dengan lancar.
\end{abstract}

Kata Kunci: Kesulitan Belajar, Membaca, Menulis, Berhitung

\section{LATAR BELAKANG}

Guru adalah orang yang memberikan ilmu kepada anak didik (Djamarah, 2010: 7) guru memiliki peran yang sangat penting di dalam dunia pendidikan.Guru juga menempati kedudukan yang terhormat di mata masyarakat karena mereka menanggap guru yang dapat mendidik siswa mereka agar menjadi pribadi yang baik. Guru mempunyai pengaruh yang besar pada siswa, guru bersama orang tua yang bersungguh-sungguh dalam membimbing dan mendidik siswa untuk rajin membaca dan belajar yang dapat mengantarkan siswa pada keberhasilan. Membaca, menulis, dan berhitung merupakan aktifitas yang paling penting dalam hidup karena dapat dikatakan bahwa semua proses belajar didasarkan pada kemampuan membaca.

Membaca, menulis dan berhitung menjadi aspek yang penting di sekolah dasar kelas rendah. Siswa harus 
menguasai aspek membaca, menulis dan berhitung. Ketiga aspek tersebut dalam pelajaran memiliki penanan sangat penting, karena dengan membaca, menulis dan berhitung anak dapat belajar berbagai macam cara untuk meningkatkan ilmu pengetahuannya, dan dapat dikatakan bahwa proses belajar didasarkan pada kemampuan membaca.

Membaca adalah kegiatan yang sangat penting dalam dunia pendidikan dan di lanjutkan dengan menulis dan berhitung, dengan keadaan yang seperti itu, merupakan salah satu kerja sama antara sekolah dengan orang tua mengenai pengenalan kemampuan calistung pada anak-anak. Walaupun dalam proses pembelajaran calistung guru sering kali menghadapi siswa yang tidak dapat mengikuti pelajaran dengan lancar, dan dapat dikatakatan guru sering menghadapi anak didik yang mengalami kesuliatan belajar apalagi untuk kelas rendah.

Pada tahun ajaran 2014-2015 ini SD Negeri 1 Pancurendang kelas 1 terdapat 39 siswa, dari 39 siswa terdapat 2 siswa yang kemampuan membaca, menulis dan berhitung belum di capai oleh mereka. Kemampuan membaca adalah kemampuan mendasar pada siswa sekolah dasar yang dilanjutkan dengan kemampuan menulis dan berhitung secara baik. Guru mengungkapkan beberapa penyebab siswa mengalami kesulitan membaca, menulis dan berhitung antara lain: siswa kurang memiliki motivasi untuk dapat membaca, kurangnya dorongan dari orang tua siswa.

\section{KAJIAN TEORI}

\section{Calistung}

Menurut Tarigan (2008:7) membaca adalah suatu proses yang dilakukan serta dipergunakan oleh pembaca untuk memperoleh pesan, yang hendak disampaikan oleh penulis melalui media kata-kata/ bahasa tulis. Tarigan (2008: 7) berpendapat bahwa membaca adalah suatu proses penyandian kembali dan pembacaan sandi. Aspek pembacaan sandi adalah menghubungkan kata-kata tulis dengan makna bahasa lisan yang mencakup pengubahan tulisan/cetakan menjadi bunyi yang bermakna.

Menurut Rahim (2008: 2) membaca permulaan adalah kegiatan membaca yang dimulai sejak anak memasuki pendidikan formal, dikatakan sebagai permulaan karena pada tahap ini merupakan tahap peralihan dari lingkungan rumah ke lingkungan sekolah.

Menulis merupakan kegiatan penting dalam proses pembelajaran setelah membaca, sesorang menulis pasti mempunyai suatu tujuan yang ingin disampaikan. Menulis adalah menurunkan atau melukiskan lambang-lambang grafik yang menggambarkan suatu bahasa yang dipahami oleh sesorang, sehingga orangorang lain dapat membaca lambanglambang grafik tersebut kalau mereka memahami bahasa dan gambaran grafik itu. Lado (Tarigan 2013 : 22).

Latihan menulis juga sangat penting untuk membantu kebiasaan anak dalam belajar menulis. Menurut Hartati (2006: 165) ada beberapa bentuk latihan menulis permulaan yang dapat dilakukan antara lain:

a. Latihan memegang pensil dan duduk untuk menulis dengan sikap dan posisi yang benar.

b. Latihan mengeblat, yaitu menirukan atau menebalkan suatu tulisan dengan menindas tulisan yang sudah ada.

c. Latihan menghubung-hubungkan tanda titik yang membentuk tulisan dapat dilakukan pada buku-buku yang secara khusus menyajikan latihan semacam ini.

d. Latihan menatap bentuk tulisan.

e. Latihan menyalin, baik dari buku pelajaran maupun dari tulisan guru pada papan tulis

f. Latihan menulis halus/indah.

g. Latihan dikte/imla.

h. Latihan melengkapi tulisan (melengkapi huruf, suku kata, dan kata) yang secara sengaja dihilangkan.

i. Menuliskan nama benda yang terdapat dalam gambar.

j. Mengarang sederhana dengan bantuan gambar. 
Sriningsih, (2008: 63) mengungkapkan bahwa kegiatan berhitung untuk anak usia dini atau sekolah dasar disebut juga sebagai kegiatan menyebutkan urutan bilangan, atau membilang buta. Berdasarkan pendapat tersebut diketahui bahwa untuk siswa kelas 1 harus mampu menyebutkan urutan bilangan tanpa menghubungkan dengan benda-benda konkrit. Pada usia kelas rendah atau kelas 1, usia 5 sampai 6 tahun dapat menyebutkan bilangan sampai seratus.

Masa masa sekolah dasar menurut Suryobroto (Djamarah, 2008: 124-125) dapat diperinci menjadi dua fase, yaitu:

Sifat khas anak-anak pada masa ini antara lain :

1) Adanya kolerasi positif yang tinggi antara keadaan kesehatan pertumbuhan jasmani dengan prestasi sekolah.

2) Adanya sikap yang cenderung untuk mematuhi peraturan-peraturan permainan yang tradisional.

3) Ada kecenderungan memuji sendiri.

4) Suka membanding-bandingkan dirinya dengan anak lain.

5) Kalau tidak bisa mmenyelesaikan satu soal, maka anak itu menganggap soal itu tidak penting.

6) Pada masa ini (terutama pada umur 68) aak menghendaki nilai (rapor) yang baik, tanpa mengingat apakah prestasinya memang pantas diberi nilai baik atau tidak.

2. Belajar dan Kesulitan Belajar

Menurut Djamarah (2008: 8) Belajar adalah serangkaian kegiatan jiwa raga untuk memproleh suatu perubahan tingkah laku sebagi hasil dari pengalaman individu dalam interaksi dengan lingkungannya yang menyangkut kognitif, afektif, dan psikomotor. Slameto (2010: 2) berpendapat bahwa belajar adalah suatu proses usaha yang dilakukan individu untuk memperoleh suatu perubahan tingkah laku yang baru secara keseluruhan, sebagai hasil pengalaman individu itu sendiri dalam kehidupan serta berinteraksi dengan lingkungannya.

Faktor-faktor yang mempengaruhi belajar siswa dapat dibedakan menjadi tiga macam, yaitu faktor internal, faktor eksternal dan faktor pendekatan belajar. Ketiga faktor tersebut saling mempengaruhi dalam proses individu sehingga menentukan kualitas belajar.

\section{METODE PENELITIAN}

Metode yang digunakan dalam penelitian ini adalah metode kualitatif dengan pendekatan analisis deskriptif. Metode kualitatif ditujukan untuk menghasilkan data deskriptif berupa katakata, tulisan atau lisan dari orang-orang dan perilakunya yang diamati.

Pengumpulan data bertujuan untuk menyesuaikan dan memperoleh data mengenai faktor-faktor apa saja yang menyebabkan siswa kesulitan membaca, menulis dan berhitung. Partisipan dalam penelitian ini yaitu siswa sekolah dasar, guru sekolah dasar. Teknik pengumpulan data harus sesuai dengan jenis penelitian yang akan digunakan untuk mendapatkan data-data yang akurat. Proses pengumpulan data dilakukan oleh peneliti itu sendiri.

Analisis data dalam penelitian ini dilakukan selama proses di lapangan dan sampai selesai. Pengumpulan data dalam proses penelitian ini menggunakan wawancara, observasi dan dokumentasi. Analisis data yang digunakan dalam penelitian ini menggunakan model Miles dan Huberman, dengan langkah yang pertama adalah mereduksi data atau memilih hal-hal yang dianggap penting selama penelitian. Langkah yang kedua adalah proses penyajian data dalam penelitian ini dengan membuat teks-teks analisis dari hasil wawancara dan observasi yang telah dilakukan. Analisis dilakukan agar peneliti lebih mudah memahami apa yang terjadi dalam proses penelitian. Langkah selanjutnya adalah menarik kesimpulan yang bersifat tetap sehingga dapat menjawab rumusan masalah.

\section{HASIL DAN PEMBAHASAN}


Hasil wawancara mengenai kemampuan membaca, menulis dan berhitung di kelas 1 SD Negeri 1 Pancurendang berdasarkan wawancara dengan guru dari jumlah 39 siswa, dari 39 siswa tersebut terdapat 2 siswa yang masih mengalami kesulitan membaca, menulis dan berhitung. Membaca, menulis dan berhitung merupakan dasar untuk siswa dalam proses pembelajaran. Anak yang sudah bisa dan lancar membaca, menulis dan berhitung akan mudah mengikuti pelajaran yang diberikan oleh guru, selain hal tersebut siswa yang sudah bisa dan lancar membaca, menulis dan berhitung akan dengan mudah menerima pelajaran dan dapat melanjutkan ke kelas selanjutnya. Modal utama pembelajaran kelas rendah terutama kelas 1 adalah menguasai membaca, menulis dan berhitung.

Keberhasilan siswa dalam membaca, menulis dan berhitung juga ditunjang oleh beberapa faktor yang mendukung, namun banyak juga faktor yang dapat mempengaruhi siswa dalam pembelajaran membaca, menulis dan berhitung.

Faktor-faktor yang mempengaruhi kesulitan membaca menulis dan berhitung Membaca, menulis dan berhitung juga masih menemukan kesulitan terutama untuk siswa kelas 1. Kesulitan membaca, menulis dan berhitung dapat dipengaruhi oleh beberapa faktor yaitu faktor internal dan faktor eksternal. Faktor internal dan eksternal dapat dilihat dari aspek psikologis yaitu keshatan fisik dari siswa, fisik yang lemah juga mempengaruhi belajar siswa, selain itu peran fungsi-fungsi fisiologis pada tubuh siswa yang sangat mempengaruhiyaitu panca indera. Panca indera sangat penting dalam proses pembelajaran. Faktor eksternaldapat dilihat dari lingkungan sosial.

Lingkungan sosial siswa, keluarga bahkan lingkungan sekitar siswa. Faktor lingkungan keluarga yang mempengaruhi kesulitan membaca, menulis dan berhitung mencakup latar belakang keluarga, cara mendidik anak dirumah dan perlakukan siswa di rumah. Faktor lingkungan yang paling berpengaruh pada kesulitan belajar membaca, menulis dan berhitung siswa adalah peran orang tua yang sudah seharusnya memperhatikan perkembangan anaknya, mendampingi, mengarahkan dan memberikan nasehat-nasehat kepada anaknya. Siswa yang dalam kegiatan belajarnya di rumah di dampingi oleh orang tuanya akan mengurangi kesuliatan belajar, karena orang tua ikut serta dalam proses pembelajaran di rumah, selain itu siswa kan lebih semangat karena orang tua sering mendampingi anaknya saat belajar. Siswa juga akan merasa senang karena merasa diperhatikan. Perhatian khusus pada anak usia dini apalagi siswa kelas 1 sangat penting untuk mengetahui setiap tumbuh kembang siswa, di samping itu pengawasan orang tua yang baik juga dapat mempengaruhi belajar siswa.

\section{SIMPULAN}

Berdasarkan hasil penelitian deskriptif faktor-faktor kesulitan membaca, menulis dan berhitung siswa kelas SD Negeri 1 Pancurendang yang telah dilaksanakan dapat disimpulkan sebaggai berikut:

1. Kemampuan membaca, menulis dan berhitung siswa kelas $1 \mathrm{SD}$ Negeri 1 Pancurendanng sebagian besar sudah lancar membaca, menulis dan berhitung dari 39 siswa hanya ada beberapa anak yang masih benar- benar mengalami kesulitan belajar yaitu 2 siswa. Selain 2 siswa tersebut siswa yang lain sudah dapat membaca, menluis dan berhitung dengan lancar. Membaca, menulis dan berhitung merupakan dasar siswa dalam melaksanakan kegiatan pembelajaran, jadi seorang siswa yang sudah lancar membaca, menulis dan berhitung akan dengan mudah mengikuti pelajran yang diberikan oleh guru.

2. Pembelajaran membaca, menulis dan berhitung di pengaruhi oleh berapa faktor yang dapat mempengaruhi kesulitan belajar anak, yaitu peran orang tua yang 
kurang memperhatikan anaknya, faktor lingkungan keluarga, lingkungan sosial, lingkungan siswa. Pendampingan orang tua dalam kegiatan belajar di rumah juga mempenngaruhi kesulitan belajar siswa, kurang perhatian khusus kepada anak dan pengawasan orang tua terhadap anaknya.teman sepermainan yang lebih dewasa, terlalu lama bermain diluar dan bermain media-media canggih seperti HP, PS dan terlalau lama menonton televisi, selain faktor tersebut juga ada fakto dari dalam diri siswa, yaitu kurangnya motivasi siswa dalam belajar membaca, menulis dan berhitung dan kurangnya minat siswa untuk belajar lebih rajin. Minat siswa juga karena disebabkan karena siswa itu sendiri, jika siswa memang dasarnya masih kurang apalagi keluarga tidak mendukung tetap saja mengalami kesulitan belajar membaca, menulis dan berhitung. faktor dari dalam diri siswa atau keturunan juga mempengaruhi kesulitan membaca, menulis dan berhitung.

3. Strategi yang dilakukan guru untuk mengatasi siswa yang belum lancar membaca, menulis dan berhitung ialah dengan terus sabar memberikan materi pembelajaran, mulai dari dasar sampi siswa lancar, membuatkan media-media yang menarik yang membuat siswa lebih semangat., selain itu kerjasama orang tua untuk mengatasi siswa yang belum lancar membaca, menulis dan berhitung.

Saran untuk penelitian ini adalah

1. Bagi guru lebih meningkatkan cara mengajar terutama strategistrategi yang dilakukan untuk membuat semua siswa lancar membaca, menulis dan berhitung. Guru juga diharapkan mampu meningkatkan minat belajar siswa, terutama kelas 1 yang berkaitan dengan membaca, menulis dan berhitung dengan memberikan media-media yang lebih menarik lagi sehingga menjadi daya tarik tersendiri oleh siswa dan menjadi lebih semangat dalam pembelajaran, selain itu dapat menumbuhkan motivasi dan minat siswa untuk lebih rajin belajar membaca, menulis dan berhitung. Media-media yang baik dann menarik dapat membantut siswa mengikuti pelajaran yang diberikan oleh guru sehingga siswa dapat dengan lancar mengikuti pelajaran dan juga meningkatkan kemampuan membaca, menulis dan berhitung siswa. Guru memberikan perhatian lebih untuk siswa yang masih mengalami kesulitan belajar dan lebih ulet, tekun serta sabar dalam memberikan materi pada setiap mata pelajaran yang berhubungan dengan memmbaca, menulis dan berhitung.

2. Bagi orang tua diharapkan terus memberikan dukungan kepada anak dalam masalah membaca, menulis dan berhitung. Orang tua juga diharapkan memotivasi siswa dengan pujian pada setiap perkembangan anak dalam membaca, menulis dan berhitung. Orang tua diharapkan menjalin kerja sama yang baik dengan guru agar mengetahui perkembangan anaknya saat menerima pelajaran dari guru terutama siswa yang sudah dan belum lancar membaca, menulis dan berhitung. Orang tua lebih memperhatikan anak pada saat belajar di rumah, dan memantau kegiatan belajar anak.

3. Bagi siswa dan siswi kelas 1 agar terus berlatih membaca, menulis dan berhitung pada saat berada di rumah, sebab masih ditemukan beberapa siswa yang masih belum lancar membaca, menulis dan 
berhitung. Siswa dan siswi kelas 1 terus mengembangkan minat untuk terus belajar dan berlatih di rumah dengan rajin. Siswa yang masih mengalami kesulitan membaca, menulis dan berhitung diharapkan lebih tekun belajar dan siswa yang sudah lancar membaca, menulis dan berhitung lebih ditingkatkan lagi belajarnya.

\section{DAFTAR PUSTAKA}

Desmita. 2011. Psikologi Perkembangan Peserta Didik. Bandung: PT Remaja Rosdakarya.

Djamarah, Syaiful Bahri. 2010. Guru Dan Anak Didik Dalam Interaksi Edukatif. Jakarta: Rineka Cipta

Djamarah, Syaiful Bahri. 2008. Psikologi Belajar. Jakarta:Rineka Cipta.
Hartati, Tatat, dkk. 2006. Pendidikan Bahasa dan Sastra Indonesia di Kelas Rendah. Bandung: Upi Press

Rahim, F. 2008. Pengajaran Membaca di

Sekolah Dasar. Jakarta: Bumi Aksara

Sriningsih, N. 2008. Standar bilangan dan operasi bilangan. Bandung. Elsindo.

Suparlan. 2006. Guru Sebagai Profesi. Yogyakarta: Hikayat Publishing.

Tarigan, Henry Guntur. 2008. Membaca Sebagai Keterampilan Berbahasa. Bandung: Angkasa.

Tarigan, Henry Guntur. 2013. Menulis Sebagai Keterampilan Berbahasa. Bandung: Angkasa. 